\title{
Herbage production-forest overstory relationships in two Arizona ponderosa pine forests
}

\author{
LUIS A. BOJORQUEZ TAPIA, PETER F. FFOLLIOTT, AND D. PHILLIP GUERTIN
}

\begin{abstract}
Abotract
Utilizing source data for annual herbage production which had been obtained through repeated measurements, though not neces. sarily taken in each year, in 2 Arizons ponderoes pine (Pinus ponderosa) forests from 1959 to 1980,18 herbage productionforest overstory regrescion equations were developed and statistically analyzed. In addition to lozarithmic and exponential transformations, a hyperbolic trand formation met the specific acceptance criteria. Solls were strattifed for some herbage components to improve sampling eficiencies. The regression equations presented are consldered more useful for lons-term planning purposes than for predicting the level of herbage production in a particular year.
\end{abstract}

Key Words: Pinus ponderoas, herbage production-forest overstory relationships

Quantitative studies describing the growth of herbaceous plants as functions of forest overstories have been conducted in many Arizona ponderosa pine forests (Ffolliott and Clary 1982, Bartlett and Betters 1983). In these studies, linear and nonlinear models generally expressed decreasing herbage production with increasing forest overstory densities (basal area, volume, crown cover) and growth rates. The production of herbaceous vegetation in ponderosa pine forests also has been related to soil parent material (Ffolliott and Clary 1975, Ffolliott and Baker 1977) and soil texture (Clary et al. 1966, Clary 1969), although these latter studies were relatively location-specific. Since the Arizona ponderosa pine forests are managed for both cattle and timber production, knowledge of herbage production-forest overstory relationships is important.

The objective of this study was to evaluate a set of regression equations relating annual herbage production to the overstories of 2 Arizona ponderosa pine forests. As a result of this evaluation, equations meeting specified acceptance criteria were identified to assist land managers in understanding the joint production of herbage and timber in these forests.

\section{Materials and Methods}

\section{Study Areas}

Source data sets from 2 study areas in Arizona ponderosa pine forests, the Beaver Creek sub-watersheds (Brown et al. 1974) and the Heber sub-watersheds (Ffolliott and Baker 1977), were utilized to develop the herbage production-forest overstory relationships described in this paper.

The ponderosa pine forest overstories on both the Beaver Creek and Heber sub-watersheds represent a simple tree species composition, but a complex spatial structure because of variations in elevation, topography, and soils, and the influence of fire. Ponderosa pine is dominant but intermixed with Douglas-fir (Pseudotsuga menziesii) and quaking aspen (Populus tremuloides) at higher elevations, and alligator (Juniperus deppeana), Utah (Juniperus osteosperma), and Rocky Mountain juniper (Juniperus scopulo-

\footnotetext{
Authors are former graduate student, professor, and assistant professor, School of Renewable Natural Resources, College of Agriculture, Univensity of Arizona, Tucson 85721 .

Manuscript accepted 24 April 1989.
}

rum), and pinyon (Pinus edulis) at lower elevations. Gambel oak (Quercus gambelii) is found scattered throughout the study areas.

The occurrence of specific herbaceous plants depends largely upon the forest overstory density, climatic patterns, physiographic characteristics, and past land use. Principal grasses and grass-like plant species on the study areas include Arizona fescue (Festuca arizonica), blue grama (Bouteloua gracilis), mountain muhly (Muhlenbergia montana), muttongrass (Poa fendleriana), bottlebrush squirreltail (Sitanion hystrix), black dropseed (Sporobolus interruptus), and sedge (Carex spp.). Important forbs and half shrubs are western ragweed (Ambrosia psilostachya), fleabane (Erigeron spp.), showy goldeneye (Viguiera multiflora), globemallow (Sphaeralcea spp.), and mullein (Verbascum spp.). Shrubs include buckbrush (Ceanothus fendleri), mountain mahogany (Cercocarpus spp.), cliffrose (Cowania mexicana), and New Mexican locust (Robinia neomexicana).

Annual temperatures and precipitation on the 2 study areas range between 7 and $9^{\circ} \mathrm{C}$ and 536 and $635 \mathrm{~mm}$, respectively, values which are similar to those observed generally in Arizona ponderosa pine forests (Schubert 1974). Two major precipitation seasons characterize the study areas. Sixty-five percent of precipitation falls from October through April, with the remainder falling in July through early September.

The soils on the Beaver Creek sub-watersheds, developed on basalt and cinders, are mostly clay loam and loam-sandy loam in texture. They have been described in detail by Williams and Anderson (1967). Soils on the Heber sub-watersheds, developed from undivided materials, unnamed but with mineralogy similar to that of the Coconico sandstone formation, are fine, sandy loam in texture. Elevations of the 2 study areas vary from 1,885 to 2,425

\section{Methods}

To develop the herbage production-forest overstory relationships, annual herbage production, measured in $\mathrm{kg}$ per ha, and forest overstory density, measured in basal area per ha, specifically in terms of $\mathrm{m}^{2}$ per ha, were measured, as described below.

Annual herbage production was measured by weight estimates (Pechanec and Pickford 1937) on permanently located $0.90-\mathrm{m}^{2}$ circular sampling plots on the Beaver Creek and Heber subwatersheds. These herbage production values, obtained through repeated measurements, were separated into 4 herbage components for analysis. These herbage components were total herbage, grasses and grass-like plants, forbs and half shrubs, and shrubs.

Herbage production was measured on the Beaver Creek subwatersheds from 1959 through 1980 . Both permanently located clusters of herbage sampling plots and forest inventory plots comprised the sampling basis. Ten clusters of 5 sampling plots each were distributed randomly to measure the herbage production on 7 sub-watersheds, totalling 3,336 ha in area. The forest inventory plots were located in systematic sampling designs with multiple random starts (Shiue 1960) on 5 of the sub-watersheds, totalling 2,089 ha in area, to sample the range of forest overstory conditions. All sampling points were not measured each year. The clusters of herbage sampling plots were measured a minimum of 3 years, while 
differing combinations of the forest inventory plots were sampled 1,2 , or 3 years in the study period. The number of sample plots for herbage production measurement and the years of measurement are presented in Table 1.

Table 1. Number of mmple plots for herbage production meaburementw on the Beaver Creek sab-waterheds.

\begin{tabular}{lcc}
\hline \hline Year & Cluster sampling plots & Foreat inventory plots \\
\hline \hline & $\mathrm{n}$ & $\mathrm{n}$ \\
1959 & 175 & \\
1960 & 350 & \\
1961 & 350 & \\
1962 & 350 & \\
1963 & 100 & \\
1964 & 150 & \\
1965 & 100 & \\
1966 & 50 & \\
1967 & 100 & \\
1968 & 150 & \\
1969 & 100 & \\
1970 & 100 & 515 \\
1971 & 100 & \\
1972 & & \\
1973 & & \\
1974 & & \\
1975 & 53 \\
1976 & 50 & \\
1977 & 570 & \\
1978 & 50 & \\
1979 & 50 & \\
1980 & 50 & \\
\hline & 50 & \\
\hline
\end{tabular}

Measurements of herbage production on Beaver Creek were separated into 3 groups to develop and subsequently evaluate the herbage production-forest overstory relationships. One group of measurements represented soils of all textures sampled. The other 2 groups of measurements, analyzed to determine whether sampling efficiencies could be improved through stratification, represented soils of either clay loam texture or soils of loam-sandy loam texture; these are the 2 soil textures most commonly found in the ponderosa pine forests on the Beaver Creek sub-watersheds. Importantly, a subset of source data for all groups, representing nearly $15 \%$ of the source data, was set aside for subsequent validation purposes.

Herbage production on the Heber sub-watersheds was measured annually on 4 small watersheds, totalling 86 ha in area, from 1974 through 1977. On each of the sub-watersheds, 30 clusters of 3 sample plots were established randomly. Approximately $10 \%$ of the data were set aside for validation purposes.

Although forest growth rates often are preferred as predictors of herbage production in ponderosa pine forests (Ffolliott and Clary 1974), forest overstory density expressed in basal area per hectare was selected as the independent variable in this study. Basal area is easily determined in the field and is utilized commonly as a basis for forest management planning. The basal area of ponderosa pine trees was estimated by variable-plot sampling techniques (Avery and Burkhart 1983) at the time of initial herbage production measurements and at the end of the study periods on the subwatersheds. Changes in basal area throughout the study period were minor, averaging less than $3 \%$.

\section{Analysis}

Since herbage production generally differs from year to year, average herbage production (by herbage component) in relation to ponderosa pine basal area levels were obtained from the repeated measurements of the sampling plots. Because a preliminary analy- sis showed that herbage production values were not related to annual precipitation, precipitation was not an independent variable in this study.

Bivariate regression analyses were employed to derive relationships that fitted the data points (Draper and Smith 1966). Dependent variables were total herbage production, and production of grasses and grass-like plants, forbs and half shrubs, and shrubs. The independent variable was ponderosa pine basal area. The following regression models, many of which have been employed previously to define herbage prociuction-forest overstory relationships (Ffolliott and Clary 1982, Bartlett and Betters 1983), were tested:

$$
\begin{aligned}
Y & =a+b(X) \\
\log Y & =a+b(X) \\
\log Y & =a+b(\log X) \\
Y & =a+b\left(X^{2}\right) \\
Y & =a+b\left(X^{3}\right) \\
Y & =a+b(X)+c\left(X^{3}\right) \\
\log Y & =a+b\left(X^{2}\right) \\
\log Y & =a+b\left(X^{3}\right) \\
\log Y & =a+b(X)+c\left(X^{3}\right) \\
(X / Y) & =a+b(X) \\
(X / Y) & =a+b(\log X) \\
\log (X / Y) & =a+b(X) \\
\log (X / Y) & =a+b(\log X) \\
(1 / X) & =a+b(X) \\
(1 / Y) & =a+b(X)+c\left(X^{2}\right) \\
Y & =a+b(X)+c(1 / X) \\
Y & =a+b(1 / X) \\
(1 / Y) & =a+b(1 / X)
\end{aligned}
$$

Descriptive statistics were computed for all of the variables in the regressions and their respective transformations. Since normality of the dependent variables was required for the " $F$ " and " $t$ " tests performed, Kolmogorov-Smirnov " $D$ " values $(a=0.5)$ were utilized to check the distributions when large kurtosis and skewness were detected for a dependent variable (Sokal and Rohlf 1979).

The herbage production-forest overstory relationships developed were evaluated by coefficients of determination $\left(r^{2}\right)$, standard errors of estimate $\left(S_{y} . x\right)$, and significance of linear regression coefficients $(\mathrm{a}=0.05)$. Only the relationships with $r^{2}$ values greater than $60 \%$ were considered for subsequent evaluation. Covariance analyses and, when the dependent variables were not normally distributed, Mann-Whitney " $U$ " tests were conducted to detect significant differences in regression slopes among the models (Sokal and Rohlf 1979).

For each herbage component in a data group, model validation entailed the following steps: observed average annual herbage production for the sampled basal arza levels and the related standard error were obtained from the subsets of source data reserved for evalution; observed basal area values were employed as inputs in the appropriate regression equation to estimate herbage production; average predicted herbage production and standard error were obtained from these estimations; and observed and predicted confidence intervals were computed $(a=0.05)$ and compared (Mankin et al. 1975). At least $70 \%$ of an observed confidence interval had to overlap the range of the predicted confidence interval for a regression equation to be accepted. If the dependent variable of a model was not normally distributed, that model was validated by the Mann-Whitney " $U$ " test. All statistical computations were carried out by the program SPSSPC (Norusis 1986).

\section{Results and Discussion}

The herbage production-forest overstory relationships presented in this paper were developed from source data collected in cutover, but recently unthinned forests. It is known that herbage production in recently thinned ponderosa pine forests can be 
greater than that in unthinned forests at similar overstory density levels (Clary and Ffolliott 1966). It is not known, however, if the difference in herbage production-forest overstory relationships between thinned and unthinned forests is short in duration. If the difference is a function of the stocking arrangement and size class distribution of the residual trees (and, therefore, affecting the penetration of light), the difference may be semipermanent in nature. Because herbage production-forest overstory relationships from unthinned ponderosa pine forests can be questionable in estimating the level of herbage production obtained by thinning, herbage production-forest overstory relationships should be redetermined when a forest overstory is reduced by thinning.

For a given ponderosa pine basal area level, the herbage production on a sub-watershed did not differ significantly from year to year. It then was found that, at a given basal area level, the herbage production on the Beaver Creek sub-watersheds generally was different from that on the Heber sub-watersheds. As a result, the herbage production data were grouped to represent, as separate entities, the Beaver Creek sub-watersheds and the Heber subwatersheds and averaged in terms of basal area for further analysis.

Regression equations for shrub production were statistically meaningless on both study areas and, therefore, were not considered. The relatively high variability in shrub production, both spatially and temporally, suggested that this herbage component was not influenced by forest overstory density. Shrub production, which often is relatively low in Arizona ponderosa pine forests, generally was higher at intermediate values of basal area and lower at the extremes of the basal area range.

\section{Beaver Creek Sub-Watersheds}

Of the 18 regression models tested for annual herbage production-forest overstory relationships on soils of igneous parent material, considering all herbage components and soil textures sampled, only the linear (1), semilogarithmic (2), polynomial (6, 7, $9)$, and hyperbolic $(12,13,15)$ models possessed $r^{2}$ values to warrant further attention. All of the regression coefficients for these models were highly significant $(a=0.01)$. However, models $(1),(6)$, (7), (12), and (15) subsequently were rejected because the overlap in the observed and predicted confidence intervals did not meet the $70 \%$ criterion for acceptance. Model (13) was rejected for total herbage production for the same reason, although it was retained in the relationships for grasses and grass-like plant production and for forb production.

Table 2 presents a summary of the selected regression equations relating herbage production to the overstories of ponderosa pine forests on the Beaver Creek sub-watersheds. The choice of which equation to use in studying the production of a particular herbage component in relation to forest overstories is largely an individual preference, as statistical differences among the equations were inconsequential, for the most part.

It was not surprising that many of the variables in the regression equations shown in Table 2 involved logarithmic or exponential transformations. In previous studies of herbage production-forest overstory relationships in Arizona ponderosa pine forests, either logarithmic or exponential transformations also were common models selected (Bartlett and Betters 1983). However, a hyperbolic transformation, model (13), also met the acceptance criteria. To the knowledge of the authors, a hyperbolic model for herbage production-forest overstory relationships in Arizona's ponderosa pine forests had not been reported previously.

To determine whether sampling efficiencies could be improved through a stratification by soil textures, regression equations describing herbage production-forest overstory relationships on soils of clay loam and loam-sandy loam were compared statistically to those presented in Table 2.
Table 2. Amnual herbage production-foreat overtiory relationahips on the Beaver Creek sub-wateribeds.

\begin{tabular}{|c|c|c|c|}
\hline Regression equation & $\mathbf{r}^{2}$ & $s_{y x}$ & $\mathbf{F}$ \\
\hline $\begin{array}{l}\text { Total herbage production: } \\
\begin{aligned}(2) \quad \log (Y) & =2.794-0.348 \times 10^{-1}(X) \\
(9) & \log (Y)=2.711-0.221 \times 10^{-1}(X) \\
& -1.130 \times 10^{-6}\left(X^{3}\right)\end{aligned}\end{array}$ & $\begin{array}{l}0.703 \\
0.765\end{array}$ & $\begin{array}{l}0.250 \\
0.231\end{array}$ & $\begin{array}{l}186.3 \\
127.0\end{array}$ \\
\hline $\begin{array}{l}\text { Grass and grass-like plant production: } \\
\begin{aligned}(2) \quad \log (Y)= & 2.517-0.294 \times 10^{-1}(X) \\
(9) \quad \log (Y)= & 2.513-0.285 \times 10^{-1}(X) \\
& -9.981 \times 10^{-7}\left(X^{3}\right) \\
\text { (13) } \log (X / Y)= & -2.681+1.596 \log (X)\end{aligned}\end{array}$ & $\begin{array}{l}0.634 \\
0.726\end{array}$ & $\begin{array}{l}0.245 \\
0.278\end{array}$ & $\begin{array}{r}133.8 \\
66.1 \\
152.6\end{array}$ \\
\hline 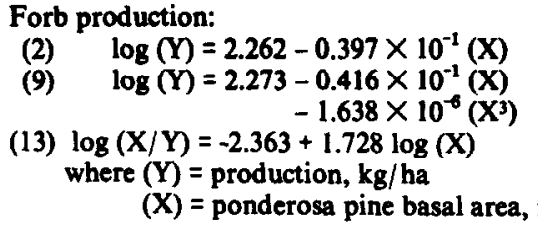 & $\begin{array}{l}0.647 \\
0.646 \\
0.623 \\
\mathrm{~m}^{2} / \mathrm{ha}\end{array}$ & $\begin{array}{l}0.322 \\
0.324 \\
0.373\end{array}$ & $\begin{array}{r}141.4 \\
70.0 \\
96.6\end{array}$ \\
\hline
\end{tabular}

For total herbage production, the regression equations for soils of clay loam texture provided higher correlations than the equations in Table 2. Therefore, a greater amount of the variation in total herbage production, as indicated by $r^{2}$ values, can be accounted for in the equations for these soils. As a result, the sampling efficiency for total herbage production could be improved through a stratification of soils on clay loam texture and the application of one of the regression equations for total herbage production in Table 3 . Correlations of the equations for total herbage production on soils of loam-sandy loam were not different $(a=0.05)$ from those presented in Table 2.

Table 3. Annual herbage production-forest overetory relationships on the Beaver Creek sub-watercheds for solls of chy loam terture.

\begin{tabular}{|c|c|c|c|}
\hline Regression equation & $\mathbf{r}^{2}$ & $\mathbf{s}_{\mathbf{y x}}$ & $\mathbf{F}$ \\
\hline $\begin{array}{l}\text { Total herbage production: } \\
\text { (2) } \log (Y)=2.773-0.309 \times 10^{-1}(X) \\
(9) \quad \log (Y)=2.809-0.320 \times 10^{-1}(X) \\
+5.927 \times 10^{-6}\left(X^{3}\right)\end{array}$ & $\begin{array}{l}0.854 \\
0.893\end{array}$ & $\begin{array}{l}0.143 \\
0.122\end{array}$ & $\begin{array}{l}164.3 \\
114.9\end{array}$ \\
\hline 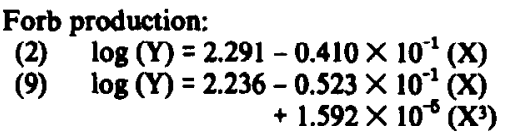 & $\begin{array}{l}0.805 \\
0.825\end{array}$ & $\begin{array}{l}0.216 \\
0.207\end{array}$ & $\begin{array}{l}119.5 \\
68.1\end{array}$ \\
\hline
\end{tabular}

Correlations of all regression equations for the production of grasses and grass-like plants, regardless of the soil texture sampled, were similar to those in Table 2 . Therefore, there is no improvement in sampling efficiency through a stratification of soil texture.

In terms of forb production, once again, the regression equations for soils of clay loam texture possessed higher correlations than those presented in Table 2. Model (13) was rejected, because it failed to meet the criteria of acceptance. Therefore, sampling efficiency could be improved through a stratification of soils of clay loam texture and use of one of the regression equations for forb production in Table 3. Correlations of the regression equations for forb production on igneous soils of loam-sandy loam texture were similar to those in Table 2.

\section{Heber Sub-Wateraheds}

Model (13) was the only model of herbage production-forest overstory relationships on the Heber sub-watersheds with $r^{2}$ values 
in excess of $60 \%$ that met the required overlap in the observed and predicted confidence intervals. This model satisfied the criteria of acceptance for all of the herbage components considered.

Table 4. Herbage production-forest overatory relationships on the Heber sub-wateriheds.

\begin{tabular}{|c|c|c|c|}
\hline Regression equation & $r^{2}$ & $\mathbf{s y y x}_{\mathbf{x}}$ & $\mathbf{F}$ \\
\hline $\begin{array}{l}\text { Total herbage production: } \\
\text { (13) } \log (X / Y)=2.633-0.216 \log (X)\end{array}$ & 0.841 & 0.252 & 554.1 \\
\hline $\begin{array}{l}\text { Grass and grass-like plant production: } \\
\text { (13) } \log (\mathrm{X} / \mathrm{Y})=-1.794+1.172 \log (\mathrm{X})\end{array}$ & 0.774 & 0.293 & 373.2 \\
\hline $\begin{array}{l}\text { Forb production: } \\
\text { (13) } \log (X / Y)=-1.601+1.254 \log (X)\end{array}$ & 0.714 & 0.363 & 267.6 \\
\hline $\begin{aligned} \text { where }(\mathbf{Y}) & =\text { production, } \mathrm{kg} / \mathrm{ha} \\
(\mathrm{X}) & =\text { ponderosa pine basal an }\end{aligned}$ & $\mathrm{m}^{2} / \mathbf{h a}$ & & \\
\hline
\end{tabular}

Table 4 shows a summary of regression equations selected to relate herbage production to the overstories of ponderosa pine forests on the Heber sub-watersheds.

\section{Management Implications}

The simultaneous production of forage for cattle production and wildlife, and timber for the production of primary wood products represents one of the best examples of multiple resource management in Arizona ponderosa pine forests (Bartlett and Betters 1983). However, to manage these forests properly for the joint production of forage and timber, an understanding of herbage production-forest overstory relationships, as described in this paper, is important.

The estimated herbage production values represent averages for given basal area levels obtained from several years of measurement on the study areas. These estimated values, therefore, are more useful for long-term planning purposes than for predicting the level of annual herbage production in a particular year. Annual herbage production could not be predicted from knowledge of precipitation or the other variables considered in this study.

Among the variables tested were annual precipitation amounts, and winter (from October through April) and summer (from May through September) precipitation. These precipitation variables were grouped to represent the current year's precipitation, the previous year's precipitation, and the accumulations of both in relation to the year of herbage production measurement. Other variables considered were topographic positions (specifically, concave swales, lower slope positions, and uplands) and elevation.

\section{Literature Cited}

Avery T.E., and H.E. Burkhart. 1983. Forest measurments. McGraw-Hill Book Co., New York.

Bartlett, E.T., and D.R. Betters. (Dds.) 1983. Overstory-understory relationships in western forests. West. Reg. Res. Pub. 1. Colorado Agr. Exp. Sta., Fort Collins.

Brown, H.E., M.B. Baker, Jr., J.J. Rogers, W.P. Clary, J.L. Kovner, F.R. Larson, C.C. Avery, and R.E. Campbell. 1974. Opportunities for increasing water yields and other multiple use values on ponderosa pine forest lands. USDA Forest Serv. Res. Pap. RM-129.

Clary, W.P. 1969. Increasing sampling precision of some herbage variables through knowled ge of the timber overstory. J. Range Manage. 22:200-201.

Clary, W.P., and P.F. Ffolliott. 1966. Differences in herbage productiontimber relationships between thinned and unthinned ponderosa pine stands. USDA Forest Serv. Res. Note RM-74.

Clary, W.P., P.F. Flolliott, and A.D. Zander. 1966. Grouping sites by soil management areas and topography. USDA Forest Serv. Res. Note RM-60.

Draper, N.R., and H. Smith. 1966. Applied regression analysis. John Wiley and Sons, Inc., New York.

Ffolliott, P.F., and M.B. Baker, Jr. 1977. Characteristics of Arizona ponderosa pine stands on sandstone soils. USDA Forest Serv. Gen. Tech. Rep. RM-44.

Ffolliott, P.F., and W.P. Chry. 1974. Predicting herbage production from forest growth in Arizona ponderosa pine. Progr. Agr. in Ariz. 26:3-5.

Ffolliott, P.F., and W.P. Clary. 1975. Differences in herbage-timber relationships on sedimentary and igneous soils in Arizona ponderosa pine stands. Prog. Agr. in Ariz. 27:6-7.

Ffolliott, P.F., and W.P. Clary. 1982. Understory-overstory vegetation relationships: An annotated bibliography. USDA Forest Serv. Gen. Tech. Rep. INT-136.

Mankin, J.B., R.V. O'Nell, H.H. Shugart, and B.W. Rust. 1975. The importance of validation in ecosystem analysis. pp. 63-71. In: Innis, G. 1975. New directions in the analysis of ecological systems, part 1. Simulation Council Proceeding Series, Vol.5, No. 1, Soc. Comp. Sim., La Jolla, Calif.

Norusis, M. 1986. SPSS/PC+ for the IBM PC/XT/AT. SPSS Inc., Chicago, IIl.

Pechanec, J., and G.D. Pickord. 1937. A weight estimate method for determination of range or pasture production. J. Amer. Soc. Agron. 29:894-904.

Schubert, G.H. 1974. Silviculture of southwestern ponderosa pine: The status of our knowledge. USDA Forest Serv. Res. Pap. RM-123.

Shiue, Chernf-Jiann. 1960. Systematic sampling with multiple random starts. Forest. Sci. 6:42-50.

Sokal, R.R., and F.J.RohH. 1979. Biometria, principios y metodos estadisticos en la investagacion biologica. H. Blume Ediciones, Madrid, Spain.

Williams, J.A., and T.C. Anderson, Jr. 1967. Soil survey of Beaver Creek area, Arizona. USDA Forest Serv. and Soil Cons. Serv., and Arizona Agr. Exp. Sta., Washington, D.C. 